\title{
World water : challenges and vision for the twenty first century
}

— L'eau dans le monde : défis et perspectives pour le vingt et unième siècle —

\author{
by Dr Mahmoud A. Abu-Zeid \\ Minister of Public Works and Water Resources Egypt \\ President of the World Water Council
}

\section{Water demand as well as pollution problems are increasing through the world. So the diverse organizations in charge of water problems have to better coordinate their actions.}

\section{E INTRODUCTION}

The World Water situation at the end of the twentieth century is reaching crises on a number of fronts at unprecedented rate and scale.

Expected water demands by far exceed available resources, plans fall short of targets, population growth is beyond control and economic downturns and environmental concerns further complicate and exacerbate efforts underway to deal with the crises. World water leaders and institutions recognize the roots and symptoms of the problem. The recognition is the first step towards resolution of the problems. This paper highlights the challenges, vision and mechanisms to deal with the world water at the end of the twentieth century. The next Century should witness serious efforts to rectify these problem through a world- wide and concerted program of action.

\section{II $\square$ THE WORLD WATER CHALLENGES}

\subsection{Water Scarcity}

The distribution of renewable fresh water in the world follows natural patterns that result in the presence of humid, and semi-arid regions. The latter regions lack natural freshwater resources and suffer from chronic shortages. With rapid population growth the demand for water increases proportionately to reach levels far exceeding the natural supply of renewable freshwater resources.

Water scarcity occurs when the demand exceeds the supply due to natural causes or due to population growth or to widespread practices that consume more water.

Agriculture is the largest user of freshwater (presently, $70 \%$ of total fresh water used in the world) to provide for the world food, natural fibers and employment to billions of the rural population. Rainfed and irrigated agriculture stand to suffer the most under water scarcity thus threatening directly the livelihood of billions, especially in developing countries.

La situation de l'eau dans le monde à la fin de ce siècle se caractérise par des crises atteignant à certains endroits une ampleur sans précédent. Ainsi, de plus en plus de pays sont confrontés à une raréfaction de l'eau, les efforts pour faciliter l'accès des populations à une eau saine sont encore insuffisants et industrie, villes et agriculture sont sources de pollution. Face à ces problèmes, les organismes de gestion de l'eau ont des actions trop fragmentaires et des conflits sont à redouter en raison des inégalités entre les pays, d'autant plus que les montants des financements du développement de la ressource en eau sont en baisse depuis la fin des années 80.

Dans ce contexte, le Conseil Mondial de l'eau s'est donné pour mission de fournir à toutes les populations de l'eau potable, une nourriture adaptée, de conserver la biodiversité, de soutenir le développement économique et de promouvoir la paix et la sécurité. 
The scarcity of water is a recent phenomenon in world history. In the 1950's there were only a handful of countries facing this problem, but in the late 1990's, it is already being felt in some 26 countries with a population of 300 million people. Projections for the year 2050 show that 66 countries with about two thirds of the world population will be facing moderate to severe water scarcity.

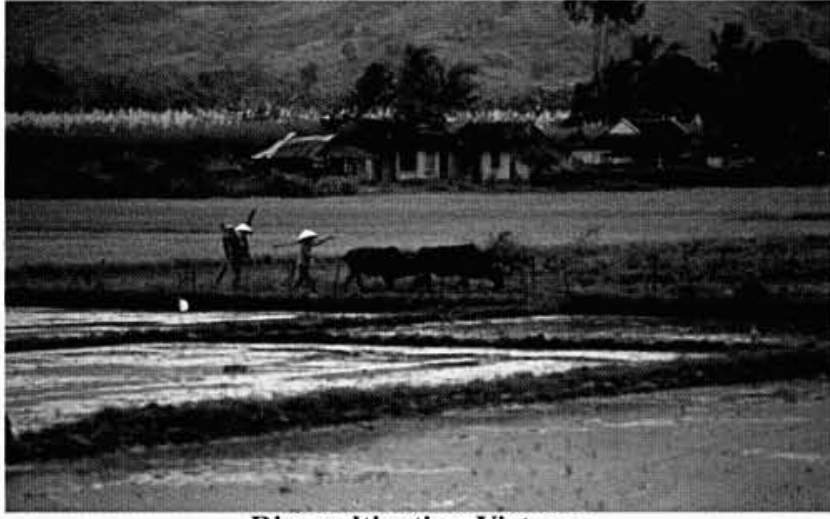

Rice cultivation Vietnam

(photothèque EDF - photo : Marc Morceau) ways carrying freshwater supplies to the communities. Intensification of agriculture results in massive increases in agrochemicals, with residues discharged to rivers, lakes and groundwater all over the world. Expansion of irrigation coupled with poor on-farm water management results in widespread waterlogging and soil salinization, especially in the arid and semi-arid regions.

There are only a few fresh water sources that are The consequences of water shortages on economic and social development, political stability and preservation of life are immeasurable.

Curbing the demand by reducing the consumption, recycling and reusing of waste water will help to some extent in augmenting the supply. Filling the gap from non-conventional sources will address the other side of the equation. There are technological, economical and environmental limits on these two solution strategies, and all these limits must be challenged to help move towards an integrated and universal solution.

Floods and drought and the effects of climatic changes add another dimension that extends water scarcity to nontraditional regions of the world. Present day infrastructures will not be able to cope with future problems adequately. A great deal of work in these areas is needed to avoid widespread of scarcity and shortages of water of seasonal or permanent nature.

\subsection{Lack of Accessibility}

Tremendous development has taken place in the last two decades to improve accessibility to clean drinking water and adequate sanitation facilities around the world. However more than 1.2 billion people still lack access to clean drinking water and 2.9 billion lacked access to adequate sanitation facilities, resulting in the annual death of 5 million persons, mostly children, from water born diseases. At the current rate of population growth and low investment in water infrastructure the situation is expected to worsen. Providing adequate access to affordable clean drinking water and sanitation to all mankind is an enormous challenge at present and for the future as well.

Addressing the gender issues is essential to ensure equity in water distribution and management.

The vulnerable segments of the populations, the poor, women and children suffer the most when adequacy, accessibility and affordability of water are critical. Sound policies and effective implementation is needed to prevent this additional suffering.

\subsection{Water quality deterioration}

Industrialization and urbanization produce large volumes of effluent wastewater discharged in most cases to water- considered to be in a pollution-free natural state.

The impacts of water quality deterioration on human health, devastation of natural habitat, biodiversity and in reducing the volume of usable water are evident all over the world.

The projected spread of mega-cities and rapid industrialization in many parts of the world can only accentuate the problem if drastic measures are not taken on time to deal with the waste treatment and pollution control adequately.

\subsection{Fragmentation of Water Management}

At the global level, water management is divided among several United Nations organizations, a multitude of international professional and scientific societies and numerous non-governmental organizations. At national levels the situation is further divided among hundreds or thousands of jurisdictions, authorities, municipalities, private sector or left unattended.

This institutional set-up leads to competition among users, conflicts, duplication of efforts and contradictory policies plans and actions. It perpetuates waste of resources and decreases efficiency in use, exacerbates inequity in allocation and hinders any reasonable attempts to coordinate efforts.

It is essential that institutional issues including policies, strategies and legal framework be harmonized and coordinated at rational levels, between nations and at the global levels as well. This is a prerequisite enabling environment to solving water problems at any and all levels.

\subsection{World peace and security}

Shortage of water due to scarcity or deterioration of its quality affects directly the economic and social development of the society. It undermines the political stability and leads to threats to peace and security.

Rich countries enjoy abundance of fresh water resources while most poor nations are facing the twin menaces of water scarcity and water quality deterioration at scales beyond their ability to cope with effectively. Exhaustion of water resources leads to severe environmental degradation, mostly irreversible. 
The linkages between global peace and security, environmental degradation and water problems are very evident in many parts of the world, especially in developing countries.

In a world of global community and interdependence, no one can be safe in the face of widespread threats and persistence of chronic problems. The collective wisdom should lead to collective action of global dimensions and water is central to this action.

\subsection{Awareness by decision makers and the public}

Water availability is taken for granted by the public in most of the world today.

Similarly political leaders are not made fully aware of present dimensions of water crisis until disasters occur. Water crisis is not a temporary phenomenon to be dealt with in a crisis management style. It requires long term and lasting solutions beyond the short term of decisionmakers in office.

The political leaders and decision-makers must be made fully aware of the magnitude of the problem at the local, national and global levels. This is needed to devise appropriate policies, strategies and action plans and to create the enabling environment for their implementation.

Without full participation of the public at all levels, it is not possible to envisage or implement sustainable solutions. Raising the awareness of the public is essential to ensure their involvement. The awareness raising involves changes in the education system, enhancing research and development, dissemination of information and enlisting the support of the civil society.

\subsection{Decline of financial resources allocation}

The world witnessed a rapid growth in financial allocations to water development in the 1960's and the 1970's spurred mainly by investment in irrigation and drinking water supply. A steady decline in financial outlay has been noted in the latter part of the 1980's and that decline became more pronounced in the 1990's.

The decline was equally noted in international development assistance, national programs and private sector investment.

The economic and financial difficulties faced by many governments and subsequent monetary policies to balance budgets and reduce deficits have resulted in drastic reductions in available financial resources for water development.

It was expected that the private sector would pick up the slack encouraged by wide adoption of market economy and privatization policies. However, such hopes did not materialize at any significant scale worldwide.

The result was a severe slowdown in water development. Funds for operation and maintenance are in limited supply. Existing schemes in need for repair and replacement are not sufficiently funded, thus declines in efficiency and continued waste of water is expected to persist for some time until the situation is reversed.

Deferred investment in new or replacement schemes is due to a lack of a clear enabling environment and sufficient atmosphere of stability and confidence to encourage the private sector to play its full role. Managing the transition for management transfer to the users groups is crucial for stimulation of financing and development.

\section{1 THE VISION AHEAD}

The World Water Council is taking the above challenges very seriously. The Council is embarking on an exercise to define clearly the World Water Vision for Life and Environment.

This ambitious task will involve wide range of consultation, research and analysis of data, experience and expectations for world water resources and utilization solutions to present and future and needed actions by the world community.

The ultimate target of the vision is to respond to the needs of the planets, its population and ecological balance.

A few of these targets that we aspire to achieve are presented below.

\subsection{Clean Drinking Water and adequate Sanitation}

Provision of clean drinking water and adequate sanitation to all human being on the planet irrespective of their stage of development, geographical location, political or cultural affiliation. A timetable and action plan to reach this objective in the shortest time possible is of utmost importance to meet the basic human needs for world population.

\subsection{Adequate Food Supply}

Food production depends directly on water availability. As a basic human needs food should be available to meet the needs of all humankind at affordable costs and with easy access and within normal limits of security.

The proximity of production to the consumers and subsistence farmers are to be given serious considerations to eliminate food shortages and protect the vulnerable poor.

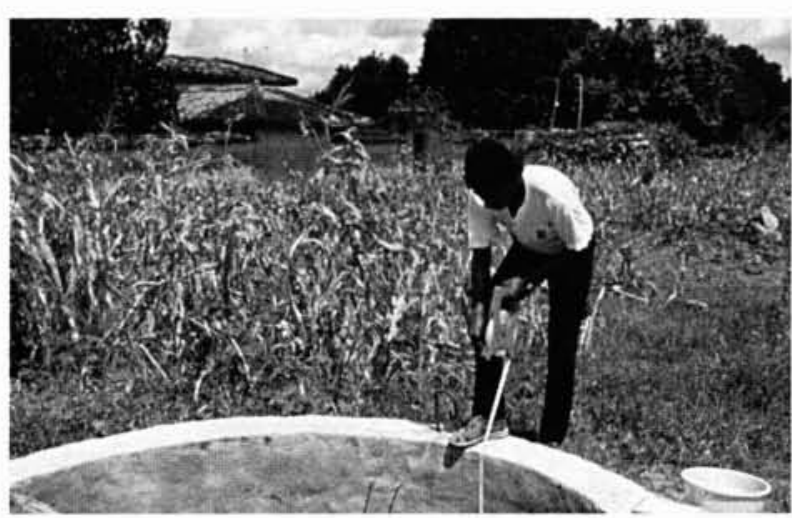




\subsection{Conservation of biodiversity}

The world heritage of biological materials which depends upon water for its existence and survival must be preserved within its natural ecological habitats. The ecological balance is an integral part of survival of life on Earth.

\subsection{Sustainable growth and economic development}

Water shall not be a limiting factor for the economic development especially for the development countries. Adequate water shall be available to meet the economic development needs within the normal market and other economic imperatives in the world.

\subsection{Promotion of world peace and security}

Conflict relating to water use at national, regional and international levels should be resolved by peaceful means to the benefits of the populations of all parties in the dispute.

Roles, principles, mechanisms and institutions are to be developed to meet all types of needs and situations of water sharing. World justice and harmony are noble objectives for the world to aspire to achieve.

\section{IV $\square$ THE MECHANISMS}

The above targets can not be achieved in isolation. They require an intricate system and complex undertakings aiming at

a) Broadening the participation at all levels of decision making and management of water ;

b) Raising the awareness of the problems, impacts and role of various institutions and civil society ;

c) Mobilizing of financial resources to undertake the arduous task of investment and development of resources ;

d) Establishing efficient and effective water management systems at all levels are essential for sustainability of world water ;

e) Development of appropriate technology for efficient water use, water saving, wastewater treatment and pollution control. 